\title{
Airport branding: content analysis of vision statements
}

\author{
Rafael Castro \\ Southern Cross University \\ Gui Lohmann, PhD \\ Griffith Aviation \\ g.lohmann@griffith.edu.au
}

\begin{abstract}
:
Following the commercialization and privatization of many airports in recent decades, airport management companies have placed greater emphasis on airport marketing and branding. One way of understanding the branding efforts of any organization is to analyze the content and themes of their vision and mission statements. In particular, vision statements provide a statement of the future intentions of companies with respect to their plans to engage with their main stakeholders. This paper aims to contribute to the literature on airport branding by analyzing the content of 91 vision statements of airports from around the world. The analytical framework involves deductive measurement and a content analysis regarding keywords identified in a literature review, in addition to tourism-related elements in airport vision statements. Although there is an intrinsic relationship between airports and tourism development, the academic literature has not thoroughly addressed stakeholder engagement among airports and tourism organizations. For the data analysis in this study, airports were segmented with respect to geographic location, passenger movement, and airport governance models.
\end{abstract}

Keywords: airport; branding; tourism destinations; vision statements

\section{Introduction}

Since the commercialization of the airport industry worldwide in the 1970 s and 1980s and the wave of privatization that followed in the 1990s, many airports have developed a strong business-oriented approach to their operations (Graham, 2008). Many airports have thus nurtured their businesses, which has led to many repercussions, including the development of airport-marketing techniques and greater business interaction with locally based nonaviation stakeholders.

In some cases, the concept of an "airport city" has emerged, with airports enhancing stakeholder engagement from a number of different perspectives, including urban transit development (Siemiatycki, 2006), environmental damage mitigation (Boons, Van Buuren, \& Teisman, 2010), planning and governance (Donnet \& Keast, 2014), and corporate social responsibility (Skouloudis, Evangelinos, \& Moraitis, 
2012). Although an intrinsic relationship exists between airports and tourism development, studies on business and governance arrangements between airports and tourism destinations are lacking in the literature. This study aims to fill part of this research gap by investigating the presence of business- and tourism-related elements in airport vision statements. Thus, a review of the literature regarding vision statements was conducted, and then, a content analysis of 91 airport vision statements was performed based on the literature review to find evidence regarding the relationship between airport branding strategies and the presence of tourism-elements in their vision statements. The methodology applied was content analysis through a qualitative approach; QSR NVivo 10 software was used to code and assess the collected text.

\section{Literature Review}

The airport commercialization process that occurred in the 1970s and 1980s and the airport privatization in the 1990s have contributed to the emergence of a more competitive and market-oriented airport industry. Thereafter, airport marketers began to develop airport brands to differentiate themselves from their competitors while increasing customer loyalty. Paternoster (2012) explains that there was a shift in passengers' perception of airports from places with long queues, unprepared employees, dirty toilets and no fun to a service-oriented venue where excellence was the goal and strong and strategically designed brands were established.

Although branding is defined as a disciplined process in which brand awareness is built and customer loyalty is enhanced (Wheeler, 2013), the way in which airports develop their brands is complex involving a number of stakeholders with potentially different representations of the single corporate brand. According to Tse (2009), airport branding strategies must include the following elements: 1) the selection of food and beverage providers; 2) the selection of retail stores; 3) pricing strategies; 4) the architectural design and layout; 5) airport artwork; 6) services, entertainment, and amenities; 7) service staff; and 8) logos and slogans.

As emphasized by Paternoster (2008), to be considered among the best in the world, airport management must be continuously focused on defining and managing a unique brand, in addition to offering remarkable experiences. Thus, the brand together with the vision and mission statements are "two sides of the same coin" because they 
require that the airport strategically defines what must be represented to guarantee that customer experiences are positively differentiated from those of other airports.

Although several authors explain the difference between vision and mission statements (Cowley \& Domb, 2012; Kemp \& Dwyer, 2003; Sidhu, 2003), it must be noted that their meanings are frequently confused with one another and terms such as "values," "goals and strategies," and "corporate philosophy" are used in practice in formulating both types of statements. Thus, achieving a general consensus between the academic literature and the understanding of terms in the industry is challenging. For example, authors such as Collins and Porras (1997) and Quigley (1994) interpret vision statements as an aggregation of assertions about a company, which includes its mission, values, goals, and strategies. However, many companies do not have established mission and vision statements because managers do not believe that they have tangible benefits (Sidhu, 2003). In addition, one can argue that owing to the challenges to airport branding, in some cases, mission and vision statements are an imperfect representation of the business strategy, philosophy, and direction that an airport authority will follow

Vision statements have been a common subject of the business leadership strategy literature since the 1980s (Levin, 2000). Although many published studies have affirmed the importance of establishing a vision statement in implementing leadership, the literature is not consistent on this topic. Such inconsistency results in significant complications because the way that a term is defined directly affects how a vision statement is understood in practice (Kantabutra \& Avery, 2002). According to Cowley and Domb (2012), a vision statement is an assertion or image of the ideal of the company in the future that helps to inspire and empower the organization's interested parties, such as shareholders and stakeholders. The vision statement is used to project the company in the future and to visualize its ideal; it is a brand promise. Kotter (2012) refers to vision statements as a type of image that projects the company in the future and explains that a vision statement should contain implicit or explicit commentaries on why people should strive to create this particular future for a company. The same study proposes an eight-stage methodology for transforming an unsuccessful company. One of these stages includes the need to develop a vision statement and the strategies that will help clarify the direction in which a company should move, motivate the company's workers toward that direction, and coordinate the actions of different groups within the organization. The mission statement has a 
different purpose, which is to put the vision into practice and to address the purpose of the organization and what it wants to achieve (Halpern \& Graham, 2013).

Recent studies have focused on attributes of vision statements that significantly affect customer and staff satisfaction (Kantabutra, 2008b; Kantabutra \& Avery, 2010; Rafferty \& Griffin, 2004) to define a strong/weak or positive/negative vision statement. Kantabutra and Avery (2007) investigate this question with retail stores in Sydney, Australia, whereas Kantabutra (2008a) focuses on the retail sector in Bangkok, Thailand. These studies conclude that vision statements should have the following attributes (Kantabutra, 2008b):

- Conciseness. A vision statement should be brief, but its brevity should not prevent a definitive statement of the vision.

- Clarity. A vision statement should be clear and precise such that everyone understands and accepts it.

- Future orientation. It should focus on a long-term perspective of the organization and its environment and guide the organization far into the future.

- Stability. A vision statement should be general and sufficiently abstract such that it is unaffected by technological or market changes.

- Challenge. It should motivate people to work toward a desirable outcome and should challenge people to do their best.

- Abstraction. A vision statement should represent a general idea, not a specific achievement, and it is not a narrow goal that can be discarded once it has been met.

- Desirability or ability to inspire. It should represent an ideal that is worth working toward because followers will not commit to achieving a goal when they do not consider the vision to be attractive.

Cowley and Domb (2012) assume that a good vision statement should meet several criteria that complement the aforementioned attributes: (1) being based in the company's current situation and present reality while recognizing the challenges to establishing an ideal future; (2) representing stakeholders and their interests; (3) being the product of collaborative thinking instead of a collection of individual visions; and (4) inspiring and inviting people to make it a reality. 
The leader's role in communicating a company's vision is important. Kantabutra (2008b, p.129) metaphorically explains that "creating a vision means creating a power, not a place; an influence, not a destination" in an effort to teach leaders that consistency is necessary when combining visionary messages and behaviors. Quigley (1994) goes further and states that a leader's power is the ability to translate a company's vision and values into reality and the expertise to sustain such a reality.

No academic studies specifically on airport vision statements were identified in the literature, although Kemp and Dwyer (2003) provides a content analysis of mission statements for 50 international airlines to discuss the nature and purpose of the mission statements; to identify the components of an ideal mission statement for tourism and hospitality organizations; and to analyze these mission statements to ascertain their consistency with the proposed ideal. Thus, based on other studies (Low \& Lamb Jr., 2000; Williams, 2006) that analyze the content of organizational mission statements, Kemp and Dwyer (2003) suggest that an ideal mission statement has nine elements:

1. Customers. Who are the company's customers? How can their needs and expectations be met?

2. Products/Services. What are the company's main products/services?

3. Geographical Market. What is the company's competitive environment?

4. Technology. Is technology the company's primary concern?

5. Survival, growth and profitability. Is the company committed to economic objectives?

6. Philosophy. What are the company's basic beliefs, values, aspirations, and philosophical priorities?

7. Self-concept. What is the company's distinctive feature or major competitive advantage?

8. Public image. Does the company respond to social, community, and environmental concerns?

9. Staff. Are employees considered important assets of the company? 
Specific studies providing guidance for organizational vision statement content analysis, particularly with respect to aviation, were not found in the literature. Considering that no study apart from Kemp and Dwyer (2003) has provided a content analysis of organizational vision statements in the aviation sector, the authors used the elements proposed in Kemp and Dwyer's study in addition to a "tourism/place" element.

\section{Methodology}

To undertake an analysis of airport vision statements, airports located on each continent were approached to obtain their vision statements. There was no specific preference for airport size, operating characteristics, or governance model. Not all airports have their vision statements available on their publically available websites; instead, airports' vision statements are often provided on webpages dedicated to attracting investors. Furthermore, certain airports present such information in their annual reports, primarily financial reports, or master plans. Direct contact with a total of 131 airports was attempted via email or through the social media network Facebook, and a response rate of approximately 77\% (101 airports) was obtained. Thus, $69.3 \%$ of the data $(n=70)$ were collected through the airport's main website or the airport authority's website; $17.8 \%(n=18)$, from master plans or annual reports; $4.9 \%(n=5)$, from websites for investor relations; $3.9 \%(n=4)$, through email exchange with the airport; and $3.9 \%(n=4)$, via Facebook pages.

After the vision statements were collected, content analysis was performed on the data. Krippendorff (2004) defines content analysis as a research technique that is used to develop reproducible and valid contextual inferences from texts (or other objects). Using this method, it is possible to investigate texts with no theory directing or biasing the research, with the first author of this paper being responsible for explaining the meaning of the analyzed materials based on the social environment or context. Data must be analyzed holistically to reflect real-world conditions, events, and texts rather than abstractions (Jennings, 2001).

As stated by Thayer et al. (2007), content analysis typically comprehends two types of content units: the unit of analysis and the unit of observation. The latter must be examined using two measurement methods: deductive measurement and inductive measurement. Deductive measurement demands the development of specific coding 
categories prior to the content analysis itself, whereas inductive measurement enables the coding categories to emerge during the analysis. This study is based on deductive measurement because the codes were established through a literature review.

Although the data collection involved both mission statements and vision statements $(n=101)$, a preliminary analysis showed that most text related to tourism was included in vision statements, not mission statements. Therefore, for the purpose of this paper, the authors focused on the 91 vision statements in the sample (see Appendix 1). Data are presented in two different, complementary sections. First, the content of the vision statements, including the presence of a tourism element was generally analyzed. Second, airports were classified according to various attributes-

geographic region, passenger traffic, and governance model (Tretheway, 2001) - to further explore how these attributes are specifically associated with the presence or absence of a tourism element in the vision statement (see Figures 1 and 2).

[insert Figure 1 here]

[insert Figure 2 here]

The analysis in this study was performed using QSR NVivo 10 software, which is a specific computer-assisted qualitative data analysis software (CAQDAS). Thus, the texts were imported into NVivo, where they were explored and categorized. Notably, data were collected and analyzed in English because the airports were international organizations. Original text in other languages, such as Spanish and French, was translated into English by the researchers (see Appendix 1). Considering the themes identified in the literature review, and the relevant topics for this research, the vision statements in this study were coded according to the proposed elements, as shown in Figure 3.

[insert Figure 3 here]

\section{Results and Analysis}

After the data were coded - using mainly the elements proposed by Kemp and Dwyer (2003) in addition to a "tourism/place" element - most vision statements were 
found to serve the primary goal of providing an image of the company's reality in an ideal future. Thus, according to Figure 4, 56 of the airports in our sample $(61.5 \%)$ referred in their vision statements to what was coded as a "self-concept" in which the organization described itself and its airport operations in the future.

[insert Figure 4 here]

The analysis of the most-repeated words in the texts coded as self-concept reveals that most vision statements portray their airports as future leaders in (14 occurrences of the terms "leading" and "leader"), and/or "the best" at (11 occurrences of the term "best"), providing airport services for a particular market. In addition, such statements frequently clarify that operating an airport is a business like any other (nine occurrences of the term "business"), which contrasts with the claim made by Tse (2009).

Public image was represented in $20(22 \%)$ of the vision statements for airport operating companies. This element is directly related to the perception of an airport's image in the community, which may be connected to products and/or services offerings that generate economic value for the region. Although it provides some level of engagement with its catchment area, the public image code has no explicit relationship with tourism development or destination promotion.

The coded elements "philosophy" and "customers" appeared with equal frequency, at $18.7 \%$ each ( $n=17$ airports). The former is related to the company's values and philosophical priorities, as in Christchurch Airport's vision statement: “... is based on the values of achieving success through integrity, partnership, passion and innovation...." The latter can be recognized by identifying important client bases and how to meet their expectations, as in Wellington Airport's statement, which is focused on customers and operational excellence to provide better services.

Products/services $(n=15 ; 16.5 \%)$ was the next most-cited element in the vision statements. Through this important element, airports describe the products and services that they offered. Orlando International Airport's vision statement states: "...the premier intermodal transportation gateway for global commerce." The element "staff" was the next most-cited element $(n=10 ; 11 \%)$, which typically is a public demonstration that the employees are important assets of the company. This element 
is clear in Halifax Stansfield International Airport's vision statement: "Great people delivering the best airport experience in the world."

The next most-cited element was profitability $(n=8 ; 8.8 \%)$, which is a clear indication of private organizations' goals regarding profitability for their shareholders. At International Airport Benito Juarez, in Mexico City, part of the vision statement is "to project the airport profitably competitive internationally...."

The geographical market element $(n=4 ; 4.4 \%)$ is intrinsically related to the competitive environment in which airports are located and is exemplified by the vision statement of Montréal-Pierre Elliott Trudeau International Airport, which indicates that the airport has an important role as a "continental gateway and a dynamic hub for passenger traffic between Europe and the Americas." Notably, the "technology" element was not found in any of the vision statements, even though airports are dominated by high-tech devices that facilitate not only airline company operations but also the customer experience. This element might generally be omitted from airport vision statements because airport companies perceive technology to be a means to deliver their visions, not a raison d'être.

Tourism or a link with the place or region where the airport is located was mentioned by only 15 airports (16.5\%). In many respects, this may be surprising, considering that airports are the first point of contact for many travelers when they arrive at a destination and the first impression that they may have about the expected quality of their entire stay (Martín-Cejas, 2006). In addition, airports are one of the major tourism stakeholders in most destinations because tourism generally consists of small and medium-sized enterprises. For the text coding, terms or expressions directly (such as "tourists," "guests," "visitors," and "tourism") or indirectly (such as country or city names and terms and expressions such as "Kiwi experience," "welcoming," and "Thai style") related to tourism or the promotion of the destination were identified. Whereas certain airports emphasize the creation of experiences that connect customers with destinations and that develop the region as a destination, other airports focus on attracting customers to the terminal, either as inbound or outbound travelers. "Tourist" was not explicitly mentioned, but terms such as "visitors," "guests," "passengers," "tourism," and "travelers" were found, which are directly related to tourism, in addition to travelers and airport service customers. Furthermore, terms describing various locations that are part of the airport catchment areas were found, such as "Rome," "Zealand" (for New Zealand), the "Caribbean," "Nashville," 
"Orlando," and "Scotland." Table 1 lists the most common tourism-related terms and their respective frequencies. They were clustered together as places (including city or country names), experience-related terms, or travel-related terms (tourism, business, and aviation).

\section{[insert Table 1]}

In addition to looking separately at the cited words (as shown on Table 1), it is important to understand how they have been assembled into a bigger picture. Some of the vision statements that are most related to tourism promotion are quoted below. Of, note, these airports are strongly concerned with the development of a regional tourism-related experience. Further analysis is provided below in the Discussion section of the paper.

"We are committed to being the most outstanding and welcoming airport in the world, creating a uniquely Kiwi experience for our visitors, passengers and staff." (Auckland International Airport, New Zealand)

"Suvarnabhumi Airport is a first-class international airport with international standard services, in the unique Thai style..." (Suvarnabhumi Airport, Thailand)

“...to be recognised as New Zealand's leading tourism gateway..." (Christchurch Airport, New Zealand)

"... connects Switzerland with the world, welcomes its guests round the clock... and has a 'Swissness' that sets it apart." (Zurich Airport, Switzerland)

"To provide the Nashville Airports Experience through outstanding customer service, facilities and services, bringing the heartbeat of the Music City to the airport." (Nashville International Airport, USA)

As described in the Methodology section, airports were classified according to "geographic region," "governance model," and "number of passengers (pax)/year" to discern common characteristics among them that emphasize certain tourism elements in their vision statements. 


\section{Geographic region}

"Self-concept" was the most cited theme for airports in all regions. In particular, in the Asia/Pacific region, 13 airports (65\% of the subsample) referred to this element, as did seven airports in Latin America (63.6\% of the subsample). Of note, the "philosophy" theme was frequently mentioned in the vision statements of airports in Latin America $(n=6,54.5 \%)$, while "customers" was cited more frequently in Europe $(n=8,26.6 \%)$.

The majority of the 15 airports with vision statements related to tourism were from Europe ( $n=7,23.3 \%$ of the European airports analyzed) and the Asia/Pacific region $(n=4,20 \%)$, followed by North America $(n=3,13.6 \%)$. Vision statements analyzed from airports in the Middle East and Africa did not address tourism, as shown in Table 2. Europe's tourism market is known to offer consolidated and mature tourist destinations that are known worldwide, such as London or Paris, which may explain why such airports are more closely related with tourism. Most of the airports in the United States are managed and operated by city governments who are also responsible for tourism planning within the destinations. This result might indicate that integrating transport issues with tourism issues is desirable when local governments are in charge of both sectors. Airports in the Asia/Pacific region are among the most awarded airports in the world (Prideaux \& Cooper, 2002) (e.g., Singapore Changi Airport, Seoul's Incheon International, Hong Kong International Airport, and Kuala Lumpur International Airport) and, as shown in the results, have a better understanding of the importance of tourism for performance and of their roles as destination marketers and developers.

[Insert Table 2 here]

\section{Passenger movement}

Whereas "self-concept" was the theme that was most cited between airports in all categories in terms of passenger movement, none of the airports with more than 40 million passengers a year referenced tourism in their vision statements; instead, their main focus was a self-concept that concerned being the best or the model airport for the world. Such a self-conception may be identified when the most-cited words coded as "self-concept" are terms such as "best," which was cited 11 times, or "leading" and "leader," which were cited 15 times (counted as one term). The word "preferred" was 
mentioned four times and "premier," "quality," and "strong," among others, were cited twice each.

The airports with between 25 and 39.99 million pax/year were predominantly focused on self-concept $(n=12,60 \%)$, followed by public image $(n=7,35 \%)$. Generally, the airports in these two categories (with 25 million passengers per year or more) are located in major global metropolises where international tourism is highly important, although this fact is not acknowledged in their vision statements. Examples of such airports include Incheon Airport in Seoul, South Korea, which has approximately 39 million passengers per year (Incheon International Airport, 2013), and Singapore Changi Airport, which has more than 51 million passengers per year (Changi Airport Singapore, 2013). Both airports immerse customers in their respective Korean and Singaporean cultures, which invites the question as to whether and to what extent the vision statements represent the practices of the airport operating companies or whether such statements are simply part of the formalities and bureaucracy required for both the planning and management of any type of company. At Changi, a passenger in transit at the airport for at least five hours is invited to enjoy a free two-hour guided tour of the city that runs daily at regular times. Such tours are operated by Changi Airport and Singapore Airlines and aim to offer sightseeing that would eventually persuade the transit passenger to return to Singapore and stay longer on a future trip (Changi Airport Singapore, 2013).

Table 3 shows that most airports with tourism-related content in their vision statements are midsize airports, which have 15 to 24.99 million pax/year $(n=3$, 27.2\%), such as Stockholm Arlanda Airport (Sweden) and Zurich International Airport (Switzerland). Airports with the next most tourism-related content in their vision statement are smaller airports, with 5 to 14.99 million pax/year $(n=7,23.3 \%)$, such as Auckland and Christchurch International Airports (New Zealand) and Nashville International Airport (United States). This prevalence of tourism-related content is likely the result of small and medium-sized airports, such as Nice Côte D’Azur Airport (France), having developed closer relationships with tourism themes because they are part of the tourist destination, and the quality of the customer experience at the airport is essential to shaping the entire destination experience. Specifically, the Nice Côte D'Azur Airport is responsible for handling passengers with origins or destinations not only in Nice but also in other cities in the Côte D’Azur region, such as Saint Tropez, Toulon, or even Monaco. Tourism is a major 
economic force in this region (it is the main industry in Nice) because Nice is the second most important tourism destination in France, after Paris (Nice Premium, 2011).

[Insert Table 3 here]

\section{Airport governance model}

The analysis based on airports' governance models is shown in Table 4. Seven different management models were identified in the literature review (Tretheway, 2001) among the airports analyzed:

- National Government Ownership. In this model, airports are owned and operated by a national government, typically under the responsibility of a Department/Minister of Transportation that oversees airport regulation, air traffic control, air navigation, and, sometimes, the operation of a national airline. Although the airport should be directly accountable to the public and users because of the public nature of the ownership, such accountability has not been observed in most cases.

- Municipal or State Government Ownership. This model is, so far, unique to the United States. Both large and small airports in this country are typically run by a city or a state as an administrative department. This model is believed to provide a high degree of accountability and transparency. However, Tretheway (2001) indicates that airport governance varies significantly in terms of structure, the degree of transparency, powers, and accountability in the United States' versions of this model.

- Government Corporation Ownership. This governance model separates the airport system from the government administration by disconnecting operations from regulatory functions. In this case, a Department of Transportation is responsible for the establishment and enforcement of regulations for airports, but a government-owned corporation actually implements and is responsible for airport management and operations.

- Airport Authority. Tretheway (2001) indicates that this terminology has various meanings. In Canada (uniquely), this term is used to indicate a not-forprofit private sector corporate alternative to government corporation, whereas 
in the United States, the term is used to indicate for a quasi-governmental operation model.

- Joint Management. In this model, airports are governed via the corporate format, but there is some private participation in the ownership of the airport. This partial private ownership introduces these airports to a number of changes in terms of corporate governance, including more commercial orientation and more stability when governments change, for example.

- Private Corporation. Privately owned airports are those that are wholly owned by a private for-profit corporation. It is common knowledge that the nature of airport ownership and operation has experienced significant transformations in recent years. In the past, airports were strictly regulated and publicly controlled; however, because of various liberalization processes, the number of commercially oriented airports is currently rapidly increasing worldwide (Graham, 2008; Halpern \& Regmi, 2011). Private corporations that manage airports must focus on profitability to yield a return for investors. Thus, they increasingly invest in developing nonaviation revenue, including renting shops, promotional spaces, parking, and, more recently, entertainment and destination-related services (Halpern \& Graham, 2013; Lohmann, Fraga \& Castro, 2013). For private corporations, consolidating their relationship with a place as a tourist destination promoter is a greater challenge owing to bureaucratic and structural barriers. Although this corporate governance structure provides a higher degree of autonomy for airports, consolidating this relationship depends on the coordinated collaboration of the various stakeholders, particularly with public bodies responsible for the entire organization of local tourism, such as city tourism offices and destination marketing organizations.

[Insert Table 4 here]

Politics might influence the establishment of airport vision statements. Table 4 shows that $100 \%(n=4)$ of the airports that are run by national governments discussed their philosophy. The same theme was present in only $20.9 \%(n=9)$ of the vision statements of airports run by private corporations, in $8.3 \%(n=1)$ of the vision 
statements of airports run by airport authorities, $18.2 \%(n=2)$ of the vision statements of airports run by municipal governments, and in none of the vision statements of airports managed and operated by joint management, government corporations, and state governments. The evidence of government philosophy in an airport vision statement suggests that the national public management of an airport is directly affected by the political environment of the country, such as the vision statement from Maiquetía Simon Bolivar Airport in Caracas, Venezuela, to “...ensure the provision of a comprehensive service with the highest standards of excellence and social management supported by a socialist vision to build the supreme social happiness for the Venezuelan population."

As shown in Table 4, airports run by private corporations $(n=8,18.6 \%)$ and those with joint management $(n=3,60 \%)$ were distinctive regarding the tourism theme. Airports managed by municipal governments $(n=2,18.2 \%)$ were also relevant for this analysis. In the case of the last two, this relationship is fully understandable because of the major investment of public capital into such airports. A city council that plans and develops the entire tourism activity of a destination and that also runs the airport is naturally more likely to foster a relationship between the airport and the destination because there are fewer barriers and incentives are aligned well. Such is the case of Louis Armstrong New Orleans International Airport, which is managed and operated by the New Orleans City Government. In August 2001, the airport was rebranded, and its name was changed to its current name in honor of the famous native-born musician's $100^{\text {th }}$ birthday (Louis Armstrong New Orleans International Airport, 2013). San Francisco International Airport, also in the United States, is another example. The SFO Museum hosts itinerant art exhibitions from all over the world but mainly those with a theme related to California or San Francisco. The airport also encourages passengers with a long layover (four hours or more) to explore the city and the Peninsula Bay area via public transit by providing information about major tourist attractions and the best ways to reach them (San Francisco International Airport, 2013).

However, unexpectedly, the airports administered by national or state governments did not refer to location or a sense of place in their vision statements, particularly because different airports have different areas of customer attraction and frequently a single airport is the main entry and exit point for tourists in a country or state. However, what has been determined from the vision statements is that this 
analysis may not reflect what airports actually do in practice. For example, the Vancouver International Airport is operated by an airport authority and, according to the research, the airport authorities do not refer to tourism in their vision statements. In practice, this airport is a major promoter for Canadian culture and has one of the largest collections of Aboriginal art in the country, which promotes tourism in the country and provides a differentiated customer experience.

\section{Discussion and Conclusions}

With the increased pace of globalization and the transformation of airports into commercial entities, more airports are utilizing marketing and branding strategies that are similar to those of large corporations. This study has shed light on the content of 91 airport vision statements, with a particular focus on the relationship between airports and their catchment areas regarding tourism.

With most airports requiring immense areas in their catchment region and with the environmental impacts of both noise and pollution - in addition to their role as major economic generators-public image was unsurprisingly the theme with the highest representation among airports $(n=20 ; 22 \%$ of the total). Airports also serve a large clientele — ranging from airlines to passengers and the local public — with $18.7 \%$ $(n=17)$ of airports aiming to meet their main clients' expectations. Apart from these two themes, most of the topics identified in airport vision statements refer to the airport itself through its "philosophy" or "self-concept," particularly emphasizing its grandiosity as the "best" or the "leader" in providing certain types of services.

When analyzing the various vision statement themes regarding certain operational and managerial characteristics of airports, certain differences were identified. "Self-concept" was particularly evident in the Asia Pacific region and in Latin America. Asia Pacific airports analyzed in this study $(n=21)$ were predominantly airports with a private corporation (see Figure 1) governance model ( $n=17$ or $81 \%$ of this subgroup). This result was observed because airports in these regions are generally operated as private corporations, separately from the main state or national airport in their locations. Several vision statements for airports from Asia (see Appendix 1) project the idea of the airport being the "leader" or "world class." Similarly, some airports in Latin America were also managed as private corporations ( $n=5$ or $45.4 \%$ of this subgroup), which might explain the high predominance of the "self-concept." 
Regarding content related to tourism in the vision statements, the analysis with respect to passenger movements shows that small and medium-sized airports seem more inclined to focus on tourism themes than large global hubs. This result might have been observed because larger airports are more focused on competing in the global arena, as they perceive themselves to be intercontinental air transport hubs. Certain airports, such as those in Singapore and Dubai, even play important roles in the development of tourism in their regions (Lohmann et al., 2009). Europe, as one of the most tourism-oriented continents in the world, had proportionally more airports that emphasize tourism themes in their vision statements. Nevertheless, airports should be more aware of their roles as tourism promoters and facilitators and acknowledge such roles in their vision statements.

This paper focused on a content analysis of airport vision statements, and a number of related directions exist for future research. First, future studies could analyze airport vision statements with respect to Kantabutra's (2008b) attributes regarding conciseness, clarity, future orientation, stability, challenge, abstractness and desirability, or ability to inspire. Additionally, there is an overall need to conduct research on airport branding and, particularly, to differentiate how airports develop their own identities, with a focus on their catchment areas. Finally, while this study has analyzed the content of airport vision statements, a follow-up study could investigate the perception of airport and destination organization managers regarding airport vision statements.

\section{References}

Boons, F., Van Buuren, A., \& Teisman, G. (2010). Governance of sustainability at airports: Moving beyond the debate between growth and noise. Paper presented at the Natural Resources Forum.

Changi Airport Singapore (2013). Retrieved 10 April 2013, from www.changiairport.com

Collins, J. C., \& Porras, J. I. (1997). Build to last: successful habits of visionary companies. New York: Harper Business.

Cowley, M., \& Domb, E. (2012). Beyond Strategic Vision. Hoboken: Taylor and Francis.

Donnet, T., \& Keast, R. (2014). Airport enclaves bridging boundary tensions between airports and cities. In J. O'Flynn, D. Blackman \& J. Halligan (Eds.), Crossing Boundaries in Public Management and Policy: The International Experience (pp. 280-293). Oxon and New York: Routledge.

Graham, A. (2008). Managing airports: an international perspective ( $3^{\text {rd }}$ ed.). Oxford: Elsevier. 
Halpern, N., \& Graham, A. (2013). Airport marketing. Oxon and New York: Routledge.

Halpern, N., \& Regmi, U. K. (2011). What's in a name? Analysis of airport brand names and slogans. Airport Management, 6(1), 63-79.

Incheon International Airport. (2013). Retrieved 24 June 2013, from www.airport.kr/eng/

Jennings, G. (2001). Tourism research. Milton, Australia: John Wiley \& Sons Australia.

Kantabutra, S. (2008a). Vision effects in Thai retail stores: practical implications. International Journal of Retail \& Distribution Management, 36(4), 323-342.

Kantabutra, S. (2008b). What do we know about vision? The Journal of Applied Business Research, 24(2), 127-138.

Kantabutra, S., \& Avery, G. C. (2002). Proposed model for investigating relationships between vision components and business unit performance. Journal of Management and Organization, 8(2), 22-39.

Kantabutra, S., \& Avery, G. C. (2007). Vision effects in customer and staff satisfaction: an empirical investigation. Leadership \& Organization Development Journal, 28(3), 209-229.

Kantabutra, S., \& Avery, G. C. (2010). The power of a vision: statements that resonate. Journal of Business Strategy, 31(1), 37-45.

Kemp, S., \& Dwyer, L. (2003). Mission statements of international airlines: a content analysis. Tourism Management, 24, 635-653.

Kotter, J. P. (2012). Leading change. Boston: Harvard Business School Press.

Krippendorff, K. (2004). Content analysis: introduction to its methodology (2 ${ }^{\text {nd }}$ ed.). London: SAGE.

Levin, I. M. (2000). Vision revisited: telling the story of the future. The Journal of Applied Behavioral Science, 36(1), 91-107.

Lohmann, G., Albers, S., Koch, B., \& Pavlovich, K. (2009). From hub to tourist destination - An explorative study of Singapore and Dubai's aviation-based transformation. Journal of Air Transport Management, 15(5), 205-211.

Lohmann, G., Fraga, C., \& Castro, R. (2013). Transportes e Destinos Turísticos: Planejamento e Gestão. Rio de Janeiro: Campus/Elsevier.

Louis Armstrong New Orleans International Airport (2013). Armstrong International History. Retrieved 27 September 2013, from www.flymsy.com/PageDisplay.asp?p1=5715

Low, G. S., \& Lamb Jr., C. W. (2000). The measurement and dimensionality of brand associations. Journal of Product \& Brand Management, 9(6), 350-368.

Martín-Cejas, R. R. (2006). Tourism service quality begins at the airport. Tourism Management, 27(5), 874-877.

Nice Premium (2011). Le tourisme, moteur de l'économie Niçoise, confirme son standing international et sa notation AAA. Retrieved 4 October 2013, from www.nice-premium.com/actualite,42/le-tourisme-moteur-de-l-economienicoise-confirme-sa-notation-aaa, 7871.html

Paternoster, J. (2008). Excellent airport customer service meets successful branding strategy. Airport Management, 2(3), 218-226.

Paternoster, J. (2012). Great Expectations. Airport World. Retrieved 18 December 2013, from http://www.airport-world.com/item/1916-great-expectations

Prideaux, B., \& Cooper, C. (2002). Marketing and destination growth: a symbiotic relationship or simple coincidence? Journal of Vacation Marketing, 9(1), 3551. 
Quigley, J. V. (1994). Vision: how leaders develop it, share it, and sustain it. Business Horizons, 37(5), 37-41.

Rafferty, A. E., \& Griffin, M. A. (2004). Dimensions of transformational leadership: conceptual and empirical extensions. The Leadership Quarterly, 15(3), 329354.

San Francisco International Airport (2013). Day Trips from SFO. Retrieved 4 October 2013, from www.flysfo.com/shop-dine-relax/attractions

Sidhu, J. (2003). Mission statements: is it time to shelve them? European Management Journal, 21(4), 439-446.

Siemiatycki, M. (2006). Implications of private-public partnerships on the development of urban public transit infrastructure: the case of Vancouver, Canada. Journal of Planning Education and Research, 26(2), 137-151.

Skouloudis, A., Evangelinos, K., \& Moraitis, S. (2012). Accountability and stakeholder engagement in the airport industry: an assessment of airports' CSR reports. Journal of Air Transport Management, 18(1), 16-20.

Thayer, A., Evans, M., McBride, A., Queen, M., \& Spyridakis, J. (2007). Content analysis as a best practice in technical communication. Journal of Technical Writing and Communication, 37(3), 267-279.

Tretheway, M. (2001). Airport ownership, management and price regulation (pp. 70). Vancouver, Canada: The Canada Transportation Act Review Panel.

Tse, I. A. (2009). An empirical study of airport branding at selected Canadian international airports. (MBA), University of Calgary, Canada.

Wheeler, A. (2013). Designing brand identity: an essential guide for the whole branding team ( $4^{\text {th }}$ ed.). Hoboken, New Jersey: John Wiley \& Sons, Inc.

Williams, A. (2006). Tourism and hospitality marketing: fantasy, feeling and fun. International Journal of Contemporary Hospitality Management, 18(6), 482495. 


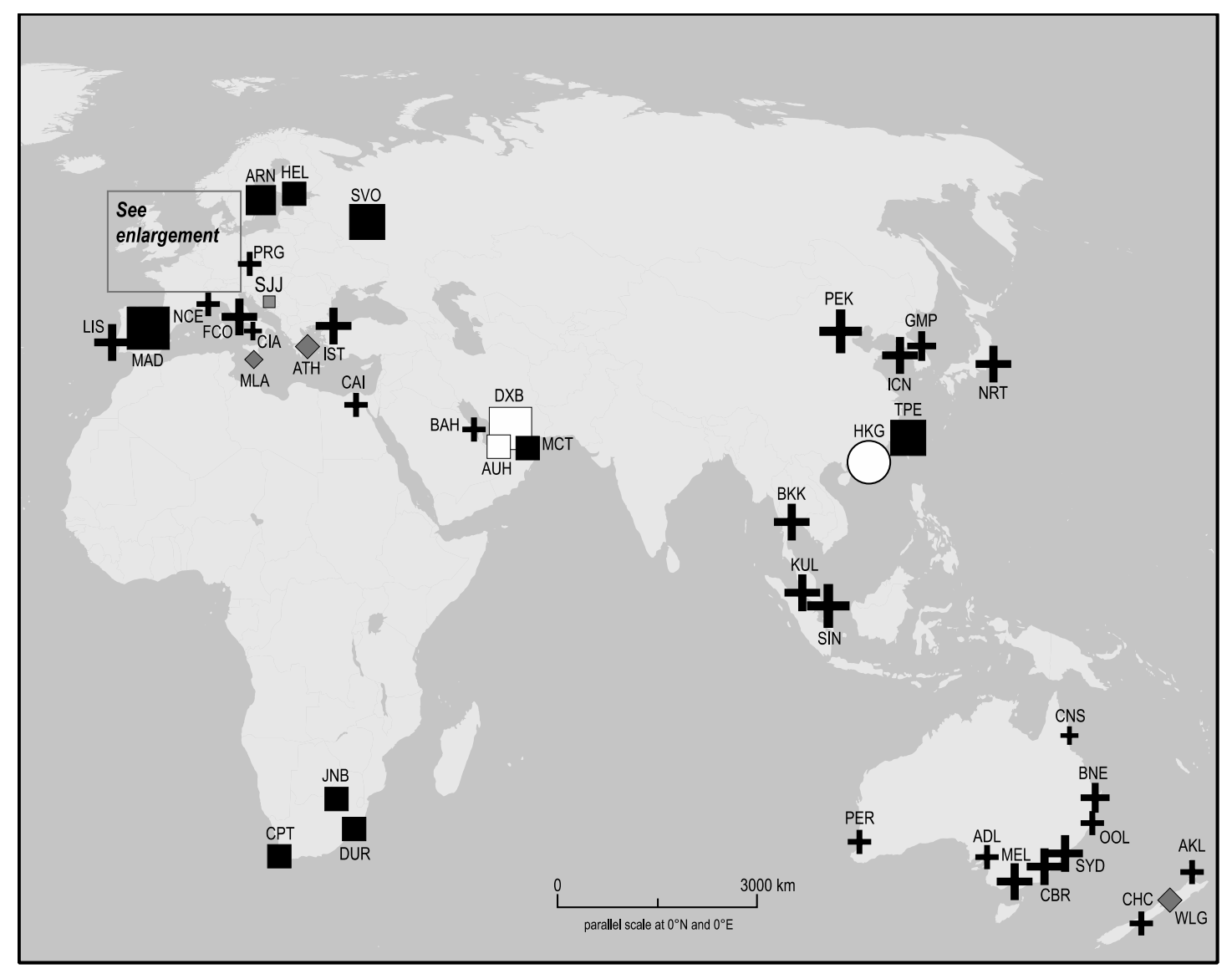

Figure 1: Airports analyzed in this study represented by governance model and annual passenger movements - Eastern Hemisphere. 


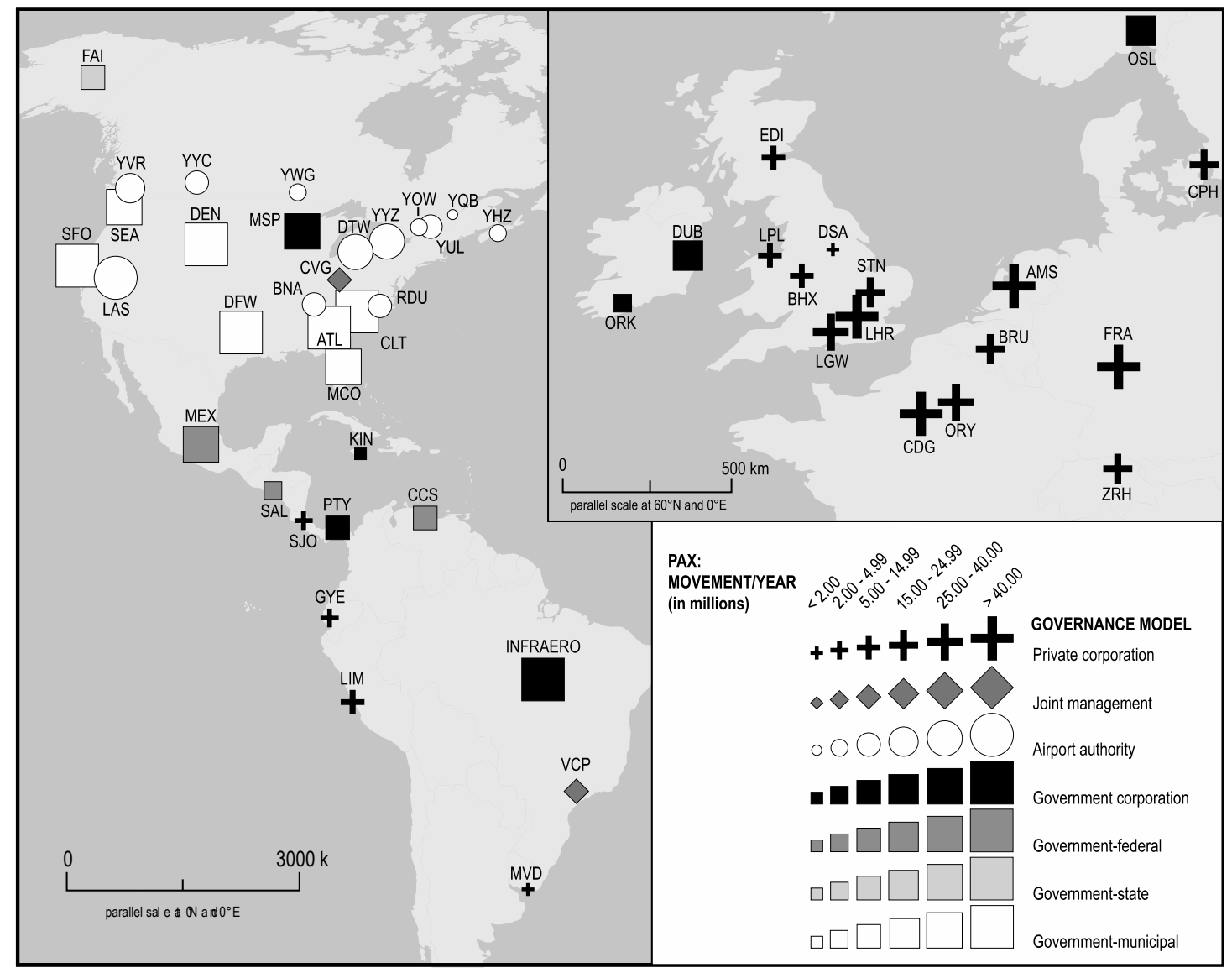

Figure 2: Airports analyzed in this study represented by governance model and annual passenger movements - Western Hemisphere. 


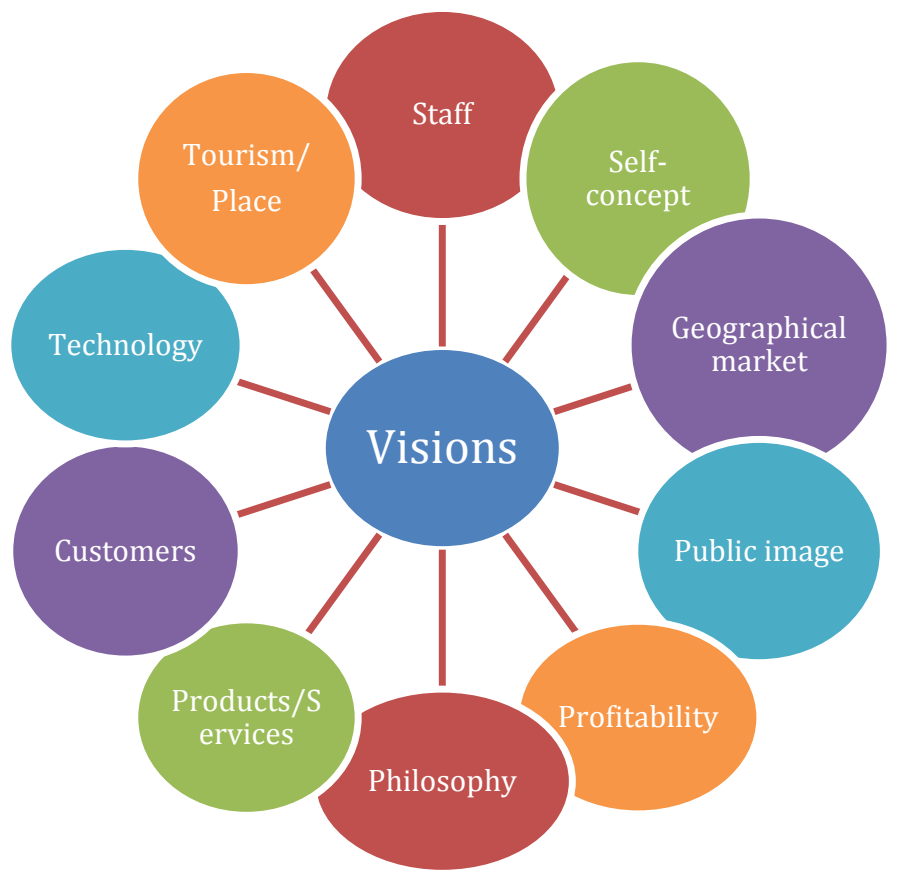

Figure 3: Text coding related to airport vision statements. 


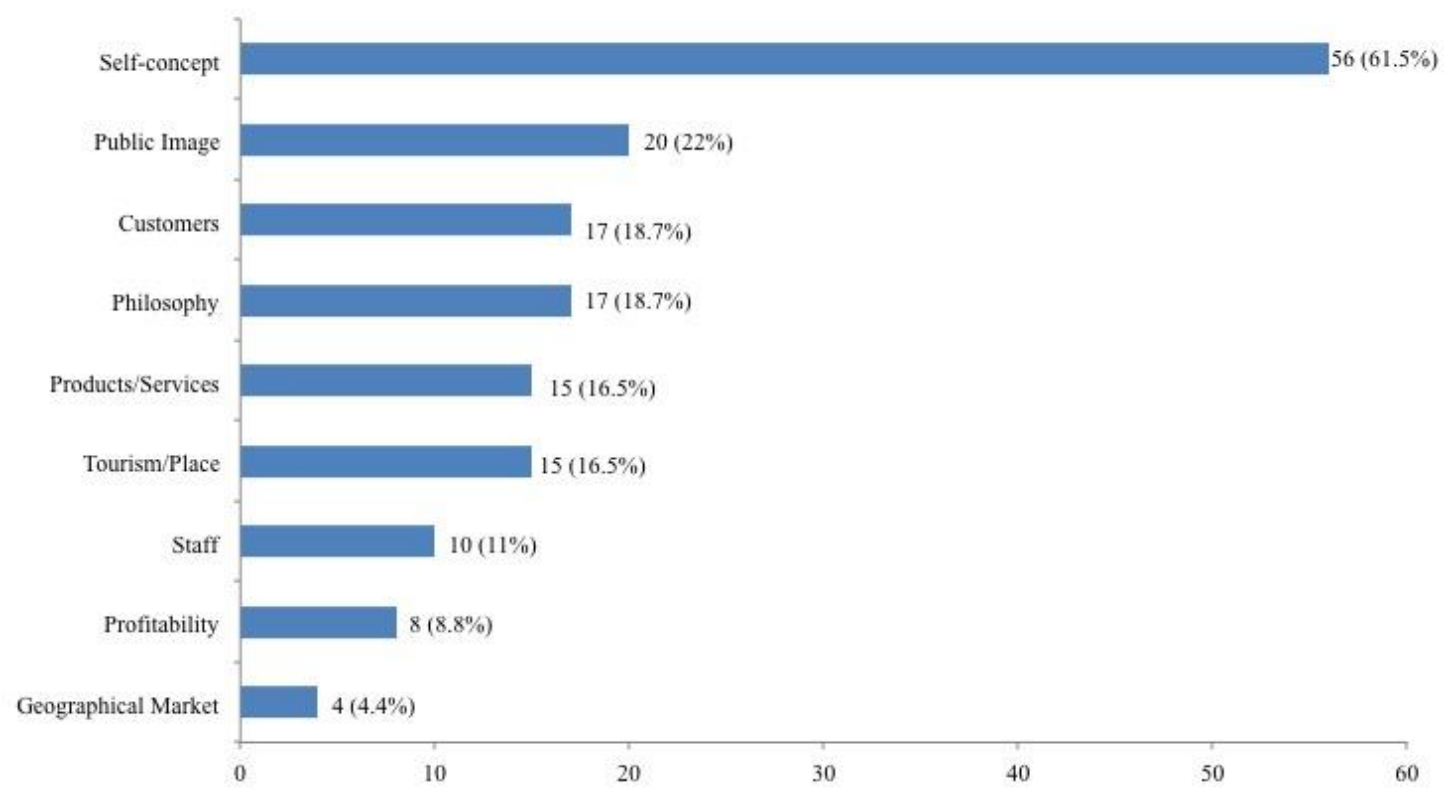

Figure 4: Frequency and percentage of airport vision statements addressing the proposed elements $(\mathrm{n}=91)$. 
Table 1: Frequency of tourism/travel element-coded words, organized by cluster.

\begin{tabular}{|c|c|}
\hline Categories & Words and Frequency \\
\hline $\begin{array}{l}\text { Place } \\
\text { (city or country } \\
\text { names) }\end{array}$ & $\begin{array}{l}\text { Rome (2); Zealand (2); Caribbean (1); Malta (1); } \\
\text { Nashville (1); Orlando (1); Scotland (1); Stockholm } \\
\text { (1); Switzerland (1); Thai (1) }\end{array}$ \\
\hline Experience & $\begin{array}{l}\text { Unique (2); experience (2); "Swissness" (1); charm } \\
\text { (1); Kiwi (1); music (1); myth (1); style (1); city (1); } \\
\text { place (1) }\end{array}$ \\
\hline Tourism & $\begin{array}{l}\text { Visitors (2); welcome (2); guest (1); tourism (1); } \\
\text { travelers (1) }\end{array}$ \\
\hline Business & $\begin{array}{l}\text { Center (2); choice (2); committed (1); dynamic (1); } \\
\text { leader (1); leading (1); link (1); partnership (1); } \\
\text { recognized (1); true (1); promoting (1); measure (1); } \\
\text { sets (1) }\end{array}$ \\
\hline Aviation & Connects (2); link (1); passengers (1) \\
\hline
\end{tabular}


Table 2: Frequency and percentage of vision statements according to coded elements and geographic region $(n=91)$.

\begin{tabular}{|c|c|c|c|c|c|c|c|c|c|c|c|c|}
\hline & & $\begin{array}{l}\text { acific } \\
20)\end{array}$ & & $\begin{array}{l}\text { merica } \\
22 \text { ) }\end{array}$ & & $\begin{array}{l}\text { merica } \\
11)\end{array}$ & & & & & & \\
\hline & $n$ & $\%$ & $n$ & $\%$ & $n$ & $\%$ & $n$ & $\%$ & $n$ & $\%$ & $n$ & $\%$ \\
\hline Tourism/Place & 4 & 20.0 & 3 & 13.6 & 1 & 9.1 & 7 & 23.3 & -- & -- & -- & -- \\
\hline Profitability & 2 & 10.0 & -- & -- & 2 & 18.2 & 4 & 13.3 & -- & -- & -- & -- \\
\hline Products/Services & 3 & 15.0 & 4 & 18.2 & 1 & 9.1 & 6 & 20.0 & -- & -- & -- & -- \\
\hline Geographical Market & 1 & 5.0 & 1 & 4.5 & -- & -- & 1 & 3.3 & -- & -- & -- & -- \\
\hline Public Image & 5 & 25.0 & 3 & 13.6 & 3 & 27.2 & 7 & 23.3 & 1 & 25 & -- & -- \\
\hline Staff & 2 & 10.0 & 4 & 18.2 & 2 & 18.2 & 1 & 3.3 & -- & -- & -- & -- \\
\hline Philosophy & 1 & 5.0 & 3 & 13.6 & 6 & 54.5 & 5 & 16.6 & 1 & 25 & -- & -- \\
\hline Customers & 4 & 20.0 & 3 & 13.6 & 1 & 9.1 & 8 & 26.6 & -- & -- & -- & -- \\
\hline Self-concept & 13 & 65.0 & 13 & 59.1 & 7 & 63.6 & 16 & 53.3 & 3 & 75 & 1 & 25 \\
\hline
\end{tabular}


Table 3: Coded elements and passenger numbers (in millions) per year (total $n=91$ ).

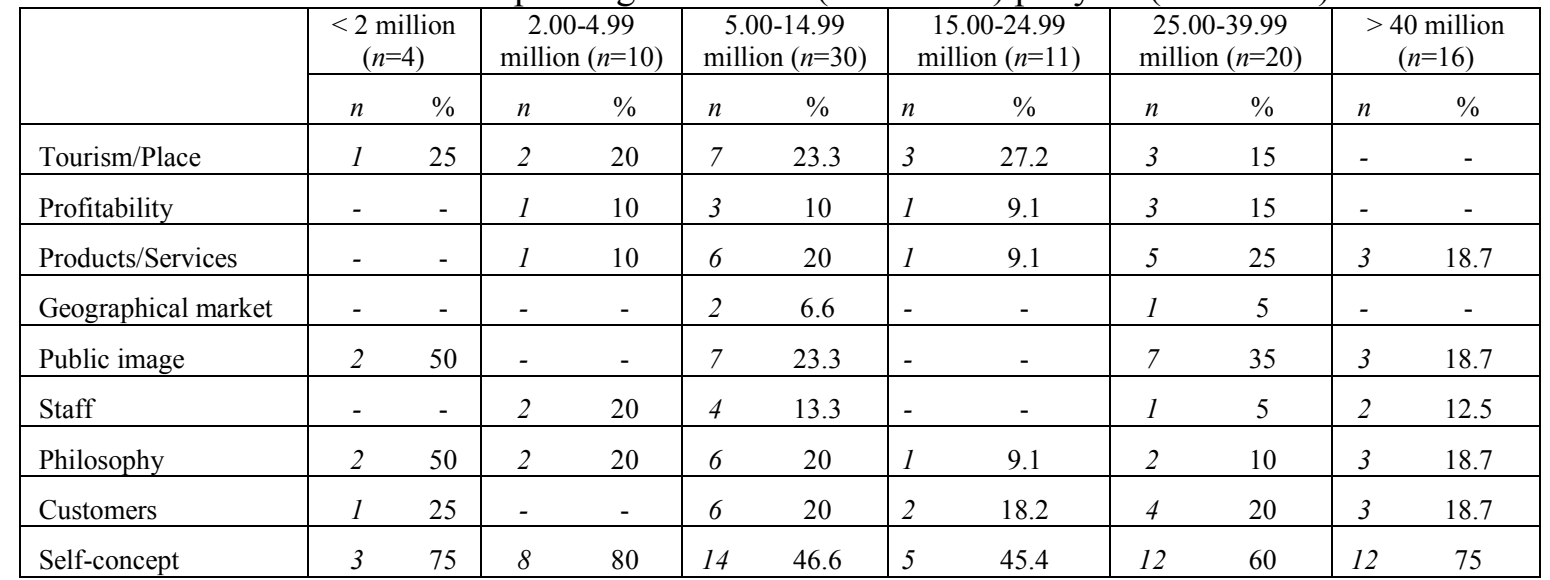


Table 4: Frequency and percentage (\%) of vision statements according to coded elements by governance model (total $n=91$ ).

\begin{tabular}{|c|c|c|c|c|c|c|c|c|c|c|c|c|c|c|}
\hline & \multicolumn{2}{|c|}{$\begin{array}{c}\text { Private } \\
\text { Corporation } \\
(n=43) \\
\end{array}$} & \multicolumn{2}{|c|}{$\begin{array}{c}\text { Airport } \\
\text { Authority } \\
(n=12) \\
\end{array}$} & \multicolumn{2}{|c|}{$\begin{array}{c}\text { Joint } \\
\text { Management } \\
(n=5) \\
\end{array}$} & \multicolumn{2}{|c|}{$\begin{array}{c}\text { National } \\
\text { Government } \\
\text { Ownership } \\
(n=4)\end{array}$} & \multicolumn{2}{|c|}{$\begin{array}{c}\text { Governmen } \\
\mathrm{t} \\
\text { Corporation } \\
(n=15) \\
\end{array}$} & \multicolumn{2}{|c|}{$\begin{array}{c}\text { Municipal } \\
\text { Government } \\
\text { Ownership } \\
(n=11) \\
\end{array}$} & \multicolumn{2}{|c|}{$\begin{array}{c}\text { State } \\
\text { Governmen } \\
\mathrm{t} \\
\text { Ownership } \\
(n=1) \\
\end{array}$} \\
\hline & $n$ & $\%$ & $n$ & $\%$ & $n$ & $\%$ & $n$ & $\%$ & $n$ & $\%$ & $n$ & $\%$ & $n$ & $\%$ \\
\hline Tourism/Place & 8 & 18.6 & - & - & 3 & 60.0 & - & - & 2 & 13.3 & 2 & 18.2 & - & - \\
\hline Products/Services & 7 & 16.3 & 1 & 8.3 & 1 & 20.0 & - & - & 2 & 13.3 & 3 & 27.3 & - & - \\
\hline $\begin{array}{l}\text { Geographical } \\
\text { Market }\end{array}$ & 2 & 4.6 & 1 & 8.3 & - & - & - & - & - & - & - & - & - & - \\
\hline Public Image & 12 & 27.9 & 2 & 16.6 & - & - & 1 & 25.0 & 2 & 13.3 & 3 & 27.3 & - & - \\
\hline Customers & 9 & 20.9 & 1 & 8.3 & 1 & 20.0 & 2 & 50.0 & 1 & 6.6 & 1 & 9.1 & 1 & 100.0 \\
\hline Self-concept & 24 & 55.8 & 9 & 75 & 4 & 80.0 & 1 & 25.0 & 11 & 73.3 & 4 & 36.4 & 1 & 100.0 \\
\hline
\end{tabular}




\section{Appendix 1:}

\begin{tabular}{|c|c|c|c|}
\hline & Airport & $\begin{array}{c}\text { IATA } \\
\text { code }\end{array}$ & Vision Statement \\
\hline \multirow{8}{*}{ 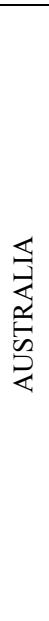 } & Sydney Intl & SYD & $\begin{array}{l}\text { At Sydney Airport, our vision is to deliver a world-class airport experience and } \\
\text { foster the growth of Sydney Airport for the benefit of Sydney, NSW and } \\
\text { Australia. }\end{array}$ \\
\hline & Melbourne Intl & MEL & $\begin{array}{l}\text { Australia will be enhanced through APAC's ongoing contribution to transport } \\
\text { infrastructure, tourism development and successful partnership that will generate } \\
\text { economic growth and long-term employment. }\end{array}$ \\
\hline & Canberra & CBR & Our vision is to develop Canberra Airport as a first-class facility. \\
\hline & Brisbane Intl & BNE & $\begin{array}{l}\text { BAC's vision for Brisbane Airport is to be world-best and the preferred choice } \\
\text { for passengers, airlines, business and the community. }\end{array}$ \\
\hline & Adelaide Intl & ADL & $\begin{array}{l}\text { To be a top tier Airport Business Centre in Asia Pacific, recognised for } \\
\text { delivering exceptional outcomes to our customers, partners, shareholders and } \\
\text { community. }\end{array}$ \\
\hline & Perth Intl & PER & To operate an outstanding airport business providing great customer service. \\
\hline & Gold Coast & OOL & $\begin{array}{l}\text { Through the skills and commitment of our people, Queensland Airports Limited } \\
\text { strives to be the benchmark for excellence in the delivery of safe and sustainable } \\
\text { regional airport facilities and services in Australia. }\end{array}$ \\
\hline & Cairns & CNS & To be a valued partner in Northern Queensland's progress \& development. \\
\hline \multirow{3}{*}{ 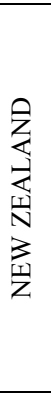 } & Auckland Intl & AKL & $\begin{array}{l}\text { We are committed to being the most outstanding and welcoming airport in the } \\
\text { world, creating a uniquely kiwi experience for our visitors, passengers and staff. }\end{array}$ \\
\hline & Wellington Intl & WLG & $\begin{array}{l}\text { We will be truly exceptional airport recognised for: our outstanding people who } \\
\text { are clear leaders in the industry; being highly innovative, efficient and agile in } \\
\text { finding new ways to deliver exceptional financial growth no matter what the } \\
\text { environment; customer focus and operational excellence; being creative in the } \\
\text { way we work, promoting New Zealand's Capital City and the region. }\end{array}$ \\
\hline & Christchurch Intl & $\mathrm{CHC}$ & $\begin{array}{l}\text { The vision of Christchurch International Airport Limited is to be recognised as } \\
\text { New Zealand's leading tourism gateway, which is based on the values of } \\
\text { achieving success through integrity, partnership, passion and innovation, with an } \\
\text { overarching goal of delivering sustainable growth in long-term shareholder } \\
\text { value. }\end{array}$ \\
\hline \multirow{4}{*}{ 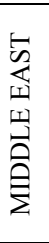 } & Dubai Intl & DXB & The World's Leading Airport Company. \\
\hline & Abu Dhabi Intl & AUH & To be the world's leading airport group. \\
\hline & Bahrain Intl & BAH & $\begin{array}{l}\text { To be the best airport for Bahrain by being professional, friendly, profitable and } \\
\text { future-ready }\end{array}$ \\
\hline & Muscat Intl & MCT & $\begin{array}{l}\text { To be a world-class organization in airports management and related businesses, } \\
\text { contributing to the prosperity of the Sultanate of Oman. }\end{array}$ \\
\hline \multirow{4}{*}{ 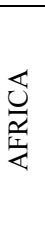 } & Cape Town Intl & CPT & Being a world-leading airport business. \\
\hline & O. R. Tambo Intl & JNB & Being a world-leading airport business. \\
\hline & King Shaka Intl & DUR & Being a world-leading airport business. \\
\hline & Cairo Intl & CAI & $\begin{array}{l}\text { Exclusivity in service, safety and security. Becoming both a passenger and cargo } \\
\text { hub in the Middle East and African continent area. }\end{array}$ \\
\hline \multirow{9}{*}{ 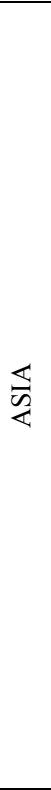 } & Changi Intl & SIN & Exceptional people, connecting lives. \\
\hline & Hong Kong Intl & HKG & $\begin{array}{l}\text { To be a world-class corporation and a leader in the airport management and } \\
\text { aviation related business, contributing to the prosperity of Hong Kong. }\end{array}$ \\
\hline & Beijing Capital Intl & PEK & To be a first-class airport management company. \\
\hline & Incheon Intl & ICN & Global airport leader creating a difference. \\
\hline & Kuala Lumpur Intl & KUL & World-class airport business. \\
\hline & Narita Intl & NRT & $\begin{array}{l}\text { As a multifunction airport capable of meeting the diverse needs for air transport } \\
\text { in the Greater Capital Area of Tokyo, Narita aims to attain the position of key } \\
\text { international hub airport of East Asia well into the future, to be the airport that is } \\
\text { relied, trusted, favored and preferred by customers. }\end{array}$ \\
\hline & Suvarnabhumi Intl & BKK & $\begin{array}{l}\text { Suvarnabhumi airport is a first-class international airport with international } \\
\text { standard services in the unique Thai style. With diversified services that provide } \\
\text { the utmost satisfaction for its users, we will be one of the top ten best airports in } \\
\text { the world and will expand the business and logistic hub in South East Asia, } \\
\text { which is important part to create economic added value for Thailand. }\end{array}$ \\
\hline & $\begin{array}{l}\text { Taiwan Taoyuan } \\
\text { Intl }\end{array}$ & TPE & $\begin{array}{l}\text { To promote the aviation industry and facilitate the growth of nonaviation } \\
\text { industries. To improve our airport operations and services and create a } \\
\text { competitive edge for Taiwan International Airport. To provide a quality and } \\
\text { convenient environment for passengers and cargo flow, to stimulate industrial } \\
\text { development and to facilitate overall national development. }\end{array}$ \\
\hline & Gimpo Intl & GMP & World-class Airports Corporation Creating Biz \& Life. \\
\hline
\end{tabular}




\begin{tabular}{|c|c|c|c|}
\hline \multirow{8}{*}{ 㴶 } & $\begin{array}{l}\text { Toronto Pearson } \\
\text { Intl }\end{array}$ & YYZ & $\begin{array}{l}\text { Toronto Pearson will be North America's premier portal to a world of } \\
\text { possibilities. }\end{array}$ \\
\hline & Vancouver Intl & YVR & Premier global gateway. \\
\hline & $\begin{array}{l}\text { Montréal-Pierre } \\
\text { Elliott Trudeau Intl }\end{array}$ & YUL & $\begin{array}{l}\text { ADM aims to become an airport manager ranking among the best in the world, } \\
\text { distinguished by the quality of its customer service as well as its rigour, } \\
\text { efficiency, and innovation. Montréal-Trudeau will expand its role as a } \\
\text { continental gateway and a dynamic hub for passenger traffic between Europe } \\
\text { and the Americas. }\end{array}$ \\
\hline & Calgary Intl & YYC & $\begin{array}{l}\text { In support of our customers, our business partners and the entire Calgary } \\
\text { community, we will operate and develop our airports in an efficient, innovative } \\
\text { and sustainable manner. }\end{array}$ \\
\hline & $\begin{array}{l}\text { Halifax Stansfield } \\
\text { Intl }\end{array}$ & YHZ & Great people delivering the best airport experience in the world. \\
\hline & Ottawa Intl & YOW & To be the Transportation Hub for the National Capital Region. \\
\hline & $\begin{array}{l}\text { Winnipeg James } \\
\text { Armstrong } \\
\text { Richardson Intl }\end{array}$ & YMG & To lead transportation innovation and growth. \\
\hline & $\begin{array}{l}\text { Québec City Jean } \\
\text { Lesage Intl }\end{array}$ & YQB & Take our place as one of Canada's ten busiest airports by 2020 . \\
\hline \multirow{14}{*}{ 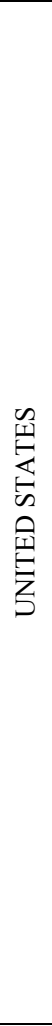 } & Denver Intl & DEN & $\begin{array}{l}\text { Together we will redefine the airport "experience" and the role an airport plays } \\
\text { in today's travel and life. Together we will soar. }\end{array}$ \\
\hline & San Francisco Intl & SFO & Reaching for No. 1. \\
\hline & $\begin{array}{l}\text { Hartsfield-Jackson } \\
\text { Atlanta Intl }\end{array}$ & ATL & $\begin{array}{l}\text { To be the global leader in airport efficiency and customer service excellence, } \\
\text { and our staff members always are ready to help your operation here succeed. }\end{array}$ \\
\hline & $\begin{array}{l}\text { Dallas/Fort-Worth } \\
\text { Intl }\end{array}$ & DFW & DFW International Airport - Connecting the world. \\
\hline & $\begin{array}{l}\text { Charlotte/Douglas } \\
\text { Intl }\end{array}$ & CLT & $\begin{array}{l}\text { We will serve as the economic engine of the Carolinas, facilitating the } \\
\text { movement of people and goods, creating jobs and enterprise and sustaining a } \\
\text { higher quality of life. }\end{array}$ \\
\hline & $\begin{array}{l}\text { Las Vegas } \\
\text { McCarran Intl }\end{array}$ & LAS & A global leader in airport management. \\
\hline & Seattle-Tacoma Intl & SEA & $\begin{array}{l}\text { Over the next } 25 \text { years we will add } 100,000 \text { jobs through economic growth led } \\
\text { by the Port of Seattle, for a total of } 300,000 \text { port-related jobs in the region, while } \\
\text { reducing our environmental footprint. }\end{array}$ \\
\hline & $\begin{array}{l}\text { Minneapolis-St } \\
\text { Paul Intl }\end{array}$ & MSP & To give our customers the best airport experience in North America. \\
\hline & $\begin{array}{l}\text { Detroit } \\
\text { Metropolitan } \\
\text { Wayne County }\end{array}$ & DTW & Making the world available. \\
\hline & Orlando Intl & $\mathrm{MCO}$ & $\begin{array}{l}\text { Advance Orlando and the region as the premier intermodal transportation } \\
\text { gateway for global commerce. }\end{array}$ \\
\hline & $\begin{array}{l}\text { Cincinnati/Norther } \\
\text { n Kentucky Intl }\end{array}$ & CVG & $\begin{array}{l}\text { To be a Safe, Smart and Strong aviation-based business that demonstrates world- } \\
\text { class professionalism with a Midwestern charm. }\end{array}$ \\
\hline & $\begin{array}{l}\text { Raleigh-Durham } \\
\text { Intl }\end{array}$ & RDU & To be a world-class airport. \\
\hline & Nashville Intl & BNA & $\begin{array}{l}\text { To provide the Nashville Airports Experience through outstanding customer } \\
\text { service, facilities and services, bringing the heartbeat of Music City to the } \\
\text { airport. }\end{array}$ \\
\hline & Fairbanks Intl & FAI & To be a world aeronexus ${ }^{\mathrm{TM}}$ \\
\hline \multirow{7}{*}{ 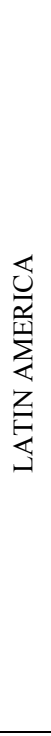 } & Brazil (Infraero) & $n / a$ & To be the Brazilian reference in airport services. \\
\hline & Benito Juarez Intl & MEX & $\begin{array}{l}\text { To project the airport profitably and competitively internationally, to face } \\
\text { challenges and opportunities with attitude, efficiency and effectiveness, and to } \\
\text { ensure safety and service quality. }\end{array}$ \\
\hline & Jorge Chavez Intl & LIM & $\begin{array}{l}\text { We are a leading aeronautical and commercial service company that operates } \\
\text { safely and efficiently, acts in accordance with our values, and works in harmony } \\
\text { with the environment. }\end{array}$ \\
\hline & $\begin{array}{l}\text { Panama Tocumen } \\
\text { Intl }\end{array}$ & PTY & $\begin{array}{l}\text { Being the best international airport in the region, renowned for the safety of air } \\
\text { operations for the quality and excellence of its passengers and freight services; } \\
\text { noted for its contribution to strategic air transport and intermodal and as a center } \\
\text { for new business opportunities. }\end{array}$ \\
\hline & $\begin{array}{l}\text { Viracopos- } \\
\text { Campinas Intl } \\
\end{array}$ & VCP & To be the best and biggest airport complex in Latin America. \\
\hline & $\begin{array}{l}\text { Maiquetía Simon } \\
\text { Bolívar Intl }\end{array}$ & $\mathrm{CCS}$ & $\begin{array}{l}\text { Being a public organization oriented and committed to efficient customer service } \\
\text { for users of Maiquetía International Airport "Simon Bolivar," meeting the } \\
\text { highest standards of national and international security, and being supported by } \\
\text { specialized human talent and the continuous improvement of technical processes } \\
\text { that ensure the provision of a comprehensive service with the highest standards } \\
\text { of excellence and social management supported by a socialist vision to build the } \\
\text { supreme social happiness for the Venezuelan population. }\end{array}$ \\
\hline & Guayaquil & GYE & $\begin{array}{l}\text { Be the best airport in the country and one of the best in America and the world, } \\
\text { thanks to our excellence, security and quality of service. }\end{array}$ \\
\hline
\end{tabular}




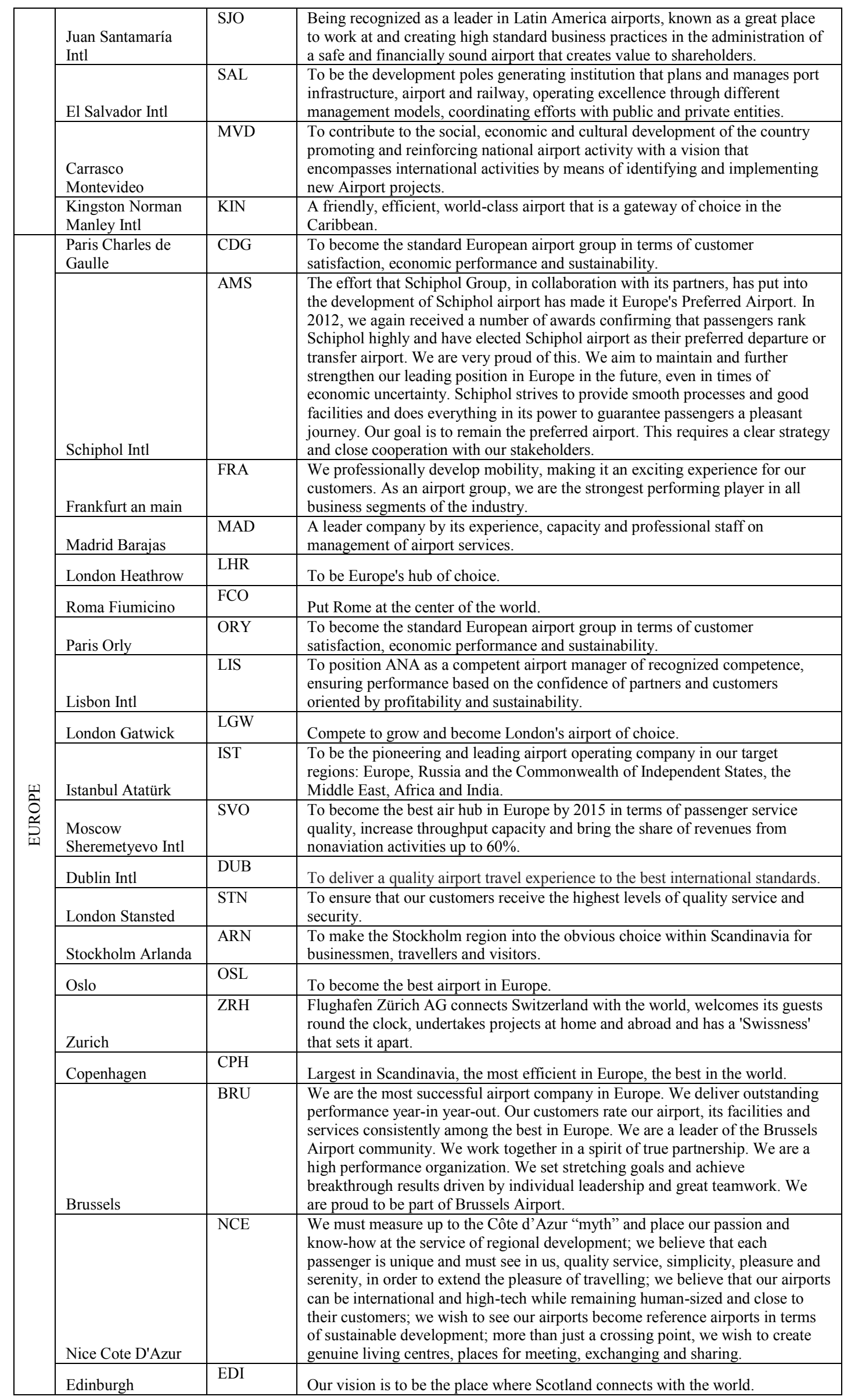




\begin{tabular}{|c|c|c|}
\hline $\begin{array}{l}\text { Liverpool John } \\
\text { Lennon }\end{array}$ & LPL & To create sustainable environments where people and business can thrive. \\
\hline Birmingham & BHX & $\begin{array}{l}\text { The airport company aims to provide for the future air transport needs of the } \\
\text { Midlands, with quality facilities and services at Birmingham International } \\
\text { Airport and within a programme of sustainable development, which balances the } \\
\text { economic importance of the airport to the region with the need for } \\
\text { environmental controls and mitigation. }\end{array}$ \\
\hline Helsinki & HEL & $\begin{array}{l}\text { To be a profitably growing, internationally oriented and well-managed service } \\
\text { company. }\end{array}$ \\
\hline Prague & PRG & We foresee future opportunities. \\
\hline Athens Intl & ATH & $\begin{array}{l}\text { To be the symbol of value creation and excellent customer experience created by } \\
\text { a vigorous and devoted airport team. }\end{array}$ \\
\hline Roma Ciampino & CIA & Put Rome at the center of the world. \\
\hline Cork & ORK & To deliver a quality airport travel experience to the best international standards. \\
\hline Malta Intl & MLA & $\begin{array}{l}\text { Our commitment towards service quality, remarkable efficiency and outstanding } \\
\text { facilities, makes Malta Airport a top airport in its class and Malta's dynamic link } \\
\text { to the world. }\end{array}$ \\
\hline $\begin{array}{l}\text { Robin Hood } \\
\text { Doncaster Sheffield }\end{array}$ & DSA & To create sustainable environments where people and business can thrive. \\
\hline Sarajevo Intl & SJJ & $\begin{array}{l}\text { To be a leading Airport in the region, recognizable by its high quality due } \\
\text { services, safety and regularity of air transport, as well as a respectable partner to } \\
\text { Airlines and other users of airport services, meeting customers' quality } \\
\text { requirements. }\end{array}$ \\
\hline
\end{tabular}

